\title{
OPTIMALISASI PRODUKSI ENZIM KITINASE PADA ISOLAT JAMUR KITINOLITIK DARI SAMPEL TANAH RIZOSFER
}

\author{
Eka Corneliyawati $^{1)}$, Massora $^{2)}$, Khikmah $^{2)}$ \& As'ad Syamsul Arifin ${ }^{3)}$ \\ ${ }^{13)}$ FPIEK, IKIP Budi Utomo, Jl. Simpang Arjuno 14B, Malang 65119 \\ ${ }^{2)}$ Fakultas Biologi, Universitas Gadjah Mada, Bulaksumur, Yogyakarta 55284 \\ E-mail: eka.corneliyawati@gmail.com
}

\begin{abstract}
The rhizosphere is the zone of soil surrounding a plant root where plant roots, soil and the soil biota interact with each other. Chitinolytic fungi has been effectively used in biological control agens. The chitinase activity causes lysis of the fungi cell wall pathogen. The aim of the research was to find optimization of activity chitinase enzyme from rhizosphere soil was conducted in vitro. Optimal growth chitinase production for TKR3 fungi isolate were concentration of chitin $0,2 \%$ $(\mathrm{b} / \mathrm{v}), \mathrm{pH} 5,5$, temperature $30^{\circ} \mathrm{C}$, agitation $150 \mathrm{rpm}$ and incubation time at four days. The optimum yield of chitinase production is influenced by fungal species and environmental conditions.
\end{abstract}

Keywords: chitinase enzyme, chitinolytic fungi, rhizosphere.

\section{PENDAHULUAN}

Rizosfer adalah tanah di sekitar akar tanaman (beberapa $\mathrm{mm}$ ) yang memiliki aktivitas mikrobiologi lebih besar dari pada daerah yang jauh dari akar tanaman (Simarmata et al., 2007). Tanah yang banyak mengandung bahan organik tinggi merupakan habitat yang cocok bagi pertumbuhan jamur. Jamur mempunyai peranan yang penting dalam proses degradasi bahan-bahan organik di tanah seperti selulosa, lignin ataupun kitin. Kitin merupakan biopolimer kedua di alam setelah selulosa dan senyawa ini dapat ditemukan pada cangkang kepiting,cangkang udang, moluska, nematoda, alga dan dinding sel jamur.

Kitin pada jamur merupakan komponen utama penyusun dinding sel jamur kelas Ascomycetes, Basidiomycetes dan Deuteromycetes. Kandungan kitin pada jamur bervariasi tergantung spesies atau strain jamurnya. Kitin pada dinding sel jamur berkisar antara 22 - 40\% (Muzzarelli, 1985).

Beberapa genera jamur yang mampu menghasilkan enzim kitinase diantaranya adalah Fusarium, Mucor, Mortierella, Trichoderma, Aspergillus, Gliocladium, Penicillium, Thamnidium dan Absidia (Alexander, 1990), Stachbotrys elegans (Tweddell et al., 1994), Verticillium biguttatum (McQuilken dan Gemmell, 2004) dan Trichothecium roseum (Li et al., 2004). Kitinase (Poli \{1,4-ß [2 asetamido-2-deoksiD-glukosamine]\} glikano hidrolase) adalah enzim yang menghidrolisis ikatan B-1,4asetamido-2-deoksi-Dglikosida dari kitin dan kitodekstrin (Bielka et al., 1984). Enzim kitinase dapat dimanfaatkan sebagai agens pengendalian jamur patogen tanaman ataupun agen pengurai limbah berkitin.

Kitinase jamur bersifat aktif pada $\mathrm{pH}$ asam, memiliki temperatur optimal yang tinggi, mempunyai berat molekul lebih dari 
30.000 Daltons, tingkat kestabilan yang tinggi dan mempunyai endokitinase dan eksokitinase (Sahai dan Manocha, 1993). Beberapa hasil penelitian sampai saat ini mengindikasikan bahwa ekspresi enzim kitinolitik bersifat indusibel. Pada umumnya ekspresi enzim akan meningkat dengan cepat apabila pada medium tumbuh mengandung kitin sebagai satu-satunya sumber karbon, yang dapat berbentuk kitin murni atau turunannya, dinding sel dan miselium jamur patogen. Induksi tidak terjadi bila jamur ditumbuhkan dalam medium yang mengandung glukosa dan beberapa gula sederhana yang lain (Harman et al., 1993).

Diasetilkitobiose merupakan substrat yang baik untuk B-N-asetilheksosamidinase tetapi tidak dapat didegradasi oleh endokitinase maupun kitobiosidase, sehingga dapat digunakan untuk membedakan aktivitas endokitinase atau kitobiosidase dan B-N-asetilheksosamidinase. Dasar inilah yang digunakan oleh Harman et al., (1993) untuk memakai koloidal kitin sebagai substrat dalam optimalisasi produksi, uji aktivitas dan purifikasi enzim endokitinase. Mengingat manfaat enzim kitinase yang cukup penting sebagai agen pengendali hayati, maka penelitian ini bertujuan untuk mengkaji optimalisasi aktivitas produksi enzim kitinase pada isolat jamur kitinolitik hasil isolasi dari sampel tanah rizosfer.

\section{METODE PENELITIAN}

Penelitian ini dilaksanakan di Laboratorium PAU Universitas Gadjah Mada, Yogyakarta. Bahan yang digunakan untuk uji optimalisasi adalah isolat jamur kitinolitik unggul (TRK3) hasil seleksi dari isolasi sampel tanah yang berasal dari tanah rizosfer tanaman kentang dan cabai.
Cara kerja

Preparasi Kitin. Preparasi atau pembuatan koloidal kitin dilakukan menurut metode Vessey dan Pegg (1973) yang dimodifikasi. Isolasi Jamur Kitinolitik. Sampel isolat jamur kitinolitik dilarutkan dalam aquades steril dan dibuat suspensi dengan tingkat pengenceran $10^{-1}-10^{-5}$, kemudian $0,1 \mathrm{ml}$ suspensi pada tingkat pengenceran $10^{-2}-10^{-5}$ diinokulasikan pada medium kitin agar. Inokulasi dilakukan dengan dua kali pengulangan. Biakan diinkubasi selama 7 hari pada temperatur $30^{\circ} \mathrm{C}$.

Optimalisasi produksi kitinase (Singh et al., 1999). Isolat terpilih ditumbuhkan dalam medium kitin cair dengan berbagai variasi kondisi meliputi konsentrasi kitin 0,2\% (b/v), $\mathrm{pH} 5,5$, temperatur inkubasi $30^{\circ} \mathrm{C}$, agitasi $150 \mathrm{rpm}$ dan waktu inkubasi 7 hari. Optimalisasi dilakukan secara bertahap dan untuk setiap tahap diukur aktivitas enzim, kadar protein total dan berat kering miselium. Konsentrasi kitin. Variasi konsentrasi kitin yang digunakan adalah 0,$1 ; 0,2$ dan $0,3 \%$ (b/v). Konsentrasi inokulum dan $\mathrm{pH}$ yang digunakan adalah hasil optimalisasi sebelumnya dan waktu inkubasi 7 hari.

pH medium. Variasi $\mathrm{pH}$ yang digunakan adalah $4 ; 4,5 ; 5 ; 5,5 ; 6 ; 6,5 ; 7$ dan 8 . Konsentrasi inokulum yang digunakan adalah hasil optimalisasi sebelumnya, sedangkan kondisi lain adalah konsentrasi kitin $0,2 \%(\mathrm{~b} / \mathrm{v})$ dan waktu inkubasi 7 hari. Temperatur inkubasi. Variasi temperatur yang digunakan adalah $30^{\circ} \mathrm{C}$ dan $37^{\circ} \mathrm{C}$. Konsentrasi inokulum, $\mathrm{pH}$ dan konsentrasi kitin yang digunakan adalah hasil optimalisasi sebelumnya dan waktu inkubasi 7 hari.

Agitasi. Variasi agitasi yang digunakan adalah 125, 150 dan $175 \mathrm{rpm}$. Konsentrasi inokulum, $\mathrm{pH}$, konsentrasi kitin dan temperatur inkubasi yang digunakan adalah 
hasil optimalisasi sebelumnya dan waktu inkubasi 7 hari.

Waktu inkubasi. Pengamatan dilakukan secara periodik setiap 24 jam selama 10 hari.

\section{HASIL DAN PEMBAHASAN}

\section{Konsentrasi kitin}

Substrat kitin yang digunakan pada penelitian ini dalam bentuk koloidal kitin, yang merupakan substrat yang dapat digunakan untuk menginduksi enzim kitinase kompleks seperti endokitinase, kitobiosidase dan $\mathrm{N}$-asetilglukosamin (Haran et al., dan Chernin et al., 1995). Variasi konsentrasi kitin yang digunakan pada optimalisasi adalah 0,$1 ; 0,2$ dan $0,3 \%$ (b/v). Kondisi pertumbuhan lainnya adalah $\mathrm{pH}$ 5,5; temperatur $30^{\circ} \mathrm{C}$, agitasi $150 \mathrm{rpm}$ dan waktu inkubasi 7 hari. Aktivitas spesifik kitinase yang diperoleh dari optimalisasi konsentrasi kitin 0,$1 ; 0,2$ dan $0,3 \% \quad(\mathrm{~b} / \mathrm{v})$ adalah 131,$6458 ; 1496,0610$ dan 319,4800 U/mg.

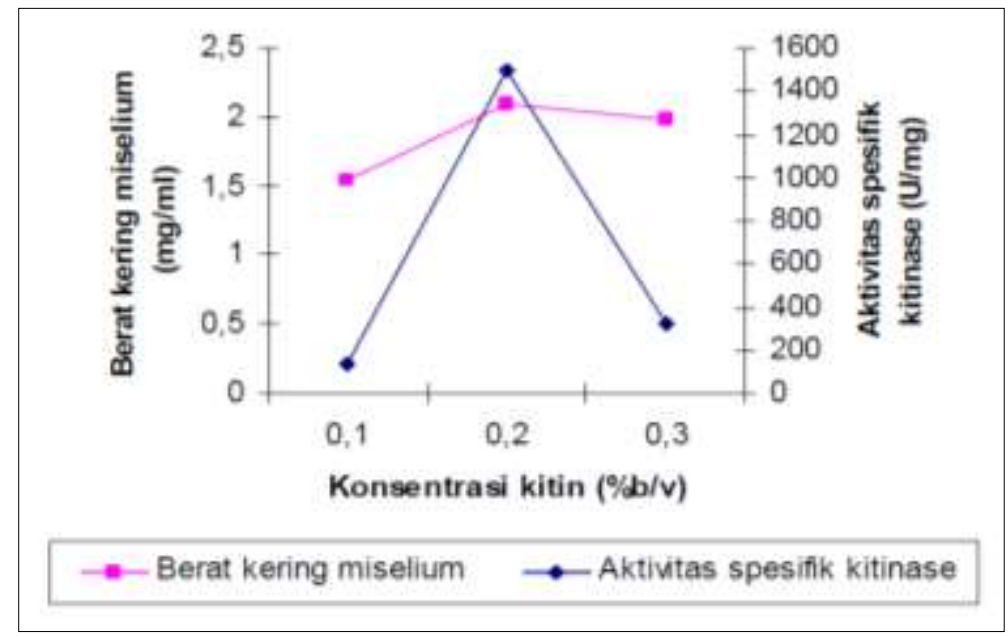

Gambar 1. Pengaruh konsentrasi kitin terhadap aktivitas spesifik kitinase dan berat kering miselium isolat jamur TRK3

Hasil optimalisasi menunjukkan bahwa konsentrasi kitin berpengaruh terhadap aktivitas spesifik kitinase. Pada konsentrasi kitin $0,1 \%$ diduga ketersediaan substrat belum cukup untuk menginduksi kitinase sehingga perombakan substrat belum maksimum. Akibatnya aktivitas spesifik juga masih belum maksimum dibandingkan pada konsentrasi kitin 0,2\%. Aktivitas enzim kitinase yang bervariasi erat kaitannya dengan ketersediaan substrat didalam medium pertumbuhannya (Wahyudi et al.,
2005). Apabila substrat cukup tersedia maka enzim kitinase akan dipacu untuk melakukan perombakan substrat.

\section{pH medium}

Variasi $\mathrm{pH} 4 ; 4,5 ; 5 ; 5,5 ; 6 ; 6,5 ; 7$ dan 8. Konsentrasi kitin $0,2 \%(\mathrm{~b} / \mathrm{v})$, temperatur $30^{\circ} \mathrm{C}$, agitasi $150 \mathrm{rpm}$ dan waktu inkubasi 7 hari. Aktivitas spesifik kitinase tertinggi diperoleh pada $\mathrm{pH}$ medium 5,5 yang merupakan $\mathrm{pH}$ optimum kitinase dalam mengkatalisis hidrolisis kitin untuk menghasilkan produk maksimum. 


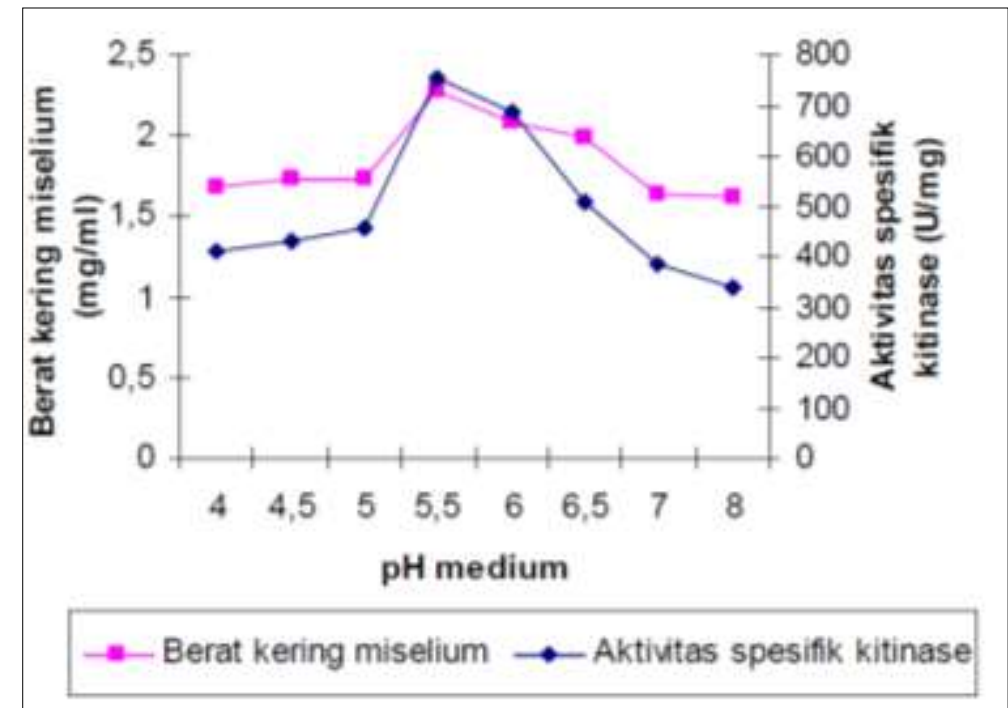

Gambar 2. Pengaruh pH medium terhadap aktivitas spesifik kitinase dan berat kering miselium isolat jamur TRK3

Enzim yang dihasilkan oleh jamur pada umumnya mempunyai $\mathrm{pH}$ optimal antara 5 dan 5,5 (Deacon, 1984),. pH medium pertumbuhan akan berpengaruh pada permeabilitas membran sitoplasmik dalam proses pengangkutan nutrien dan pada reaksi enzim. Pada saat $\mathrm{pH}$ optimum, enzim akan mempunyai konformasi sisi aktif yang sesuai dengan substrat yang mengakibatkan terbentuknya kompleks enzim substrat yang maksimal sehingga menghasilkan produk yang paling besar. Produk-produk pemecahan kitin akan dimanfaatkan oleh jamur untuk pertumbuhannya. Hal ini terlihat dari berat kering miselium yang mencapai berat maksimum 2,7000 $\mathrm{mg} / \mathrm{ml}$ pada saat aktivitas spesifik kitinase mencapai hasil optimal.

Hasil pH optimum 5,5 yang cenderung asam ini juga didukung oleh beberapa hasil penelitian sebelumnya.
Produksi kitinase akan meningkat pada $\mathrm{pH}$ asam (pH 5,5) (Elad et al., 1983). pH asam juga dilaporkan merupakan parameter pertumbuhan yang penting untuk produksi kitinase dalam mekanisme mikoparasitisme Trichoderma harzianum. Dalam penelitian yang dilakukan oleh Sandhya et al., (2004) didapatkan hasil bahwa produksi maksimum kitinase Trichoderma harzianum diperoleh pada $\mathrm{pH} 5,5$.

\section{Temperatur inkubasi}

Optimasi temperatur terhadap produksi kitinase dilakukan pada temperatur $30^{\circ} \mathrm{C}$ dan $37^{\circ} \mathrm{C}$, pH 5,5; konsentrasi kitin $0,2 \%$ (b/v), agitasi $150 \mathrm{rpm}$ dan waktu inkubasi 7 hari. Aktivitas spesifik kitinase pada temperatur $30^{\circ} \mathrm{C}$ dan $37^{\circ} \mathrm{C}$ adalah 1408,4507 dan 166,2061 U/mg. Hasil optimalisasi menunjukkan bahwa aktivitas spesifik kitinase dan pertumbuhan jamur menurun dengan meningkatnya temperatur. 


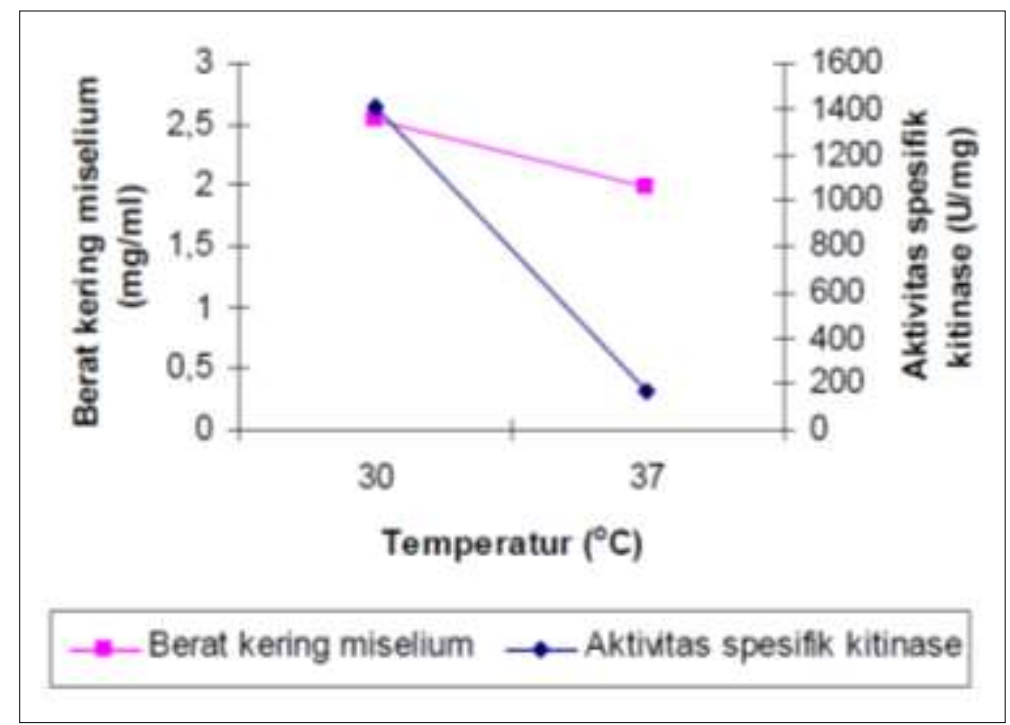

Gambar 3. Pengaruh temperatur terhadap aktivitas spesifik kitinase dan berat kering miselium isolat jamur TRK3

Pengaruh temperatur pada katalitik enzim (Murray et al., 1997). pertumbuhan jamur berhubungan dengan Sebagian besar enzim mempunyai temperatur aktivitas enzim. Aktivitas enzim akan optimal yang sesuai dengan temperatur asal semakin meningkat seiring dengan kenaikan mikroorganisme. Sebagian besar jamur temperatur sampai tingkat optimal, kemudian akan menurun. Pada temperatur $30^{\circ} \mathrm{C}$ diduga hampir semua substrat bereaksi dengan enzim yang menghasilkan produk maksimal, sehingga aktivitas spesifik kitinase menjadi optimal. Aktivitas spesifik kitinase pada temperatur $37^{\circ} \mathrm{C}$ menurun. Hal ini dikarenakan kenaikan temperatur yang melampaui temperatur optimal menyebabkan kerusakan pada gugus aktif enzim (terjadi denaturasi), sehingga enzim mengalami hambatan dalam berinteraksi dengan substrat yang menyebabkan menurunnya aktivitas adalah mesofilik dengan temperatur optimal untuk pertumbuhan $20{ }^{\circ} \mathrm{C}-35^{\circ} \mathrm{C}$ (Deacon, 1984).

\section{Agitasi}

Sebagian besar jamur bersifat aerob yang membutuhkan oksigen untuk pertumbuhannya. Suplai oksigen dalam medium pertumbuhan dapat dilakukan dengan agitasi. Aktivitas spesifik kitinase yang diperoleh dari hasil optimalisasi agitasi pada kecepatan 125, 150 dan 175 rpm berturut-turut adalah 230,6012; 442,2963 dan $88,9483 \mathrm{U} / \mathrm{mg}$. 


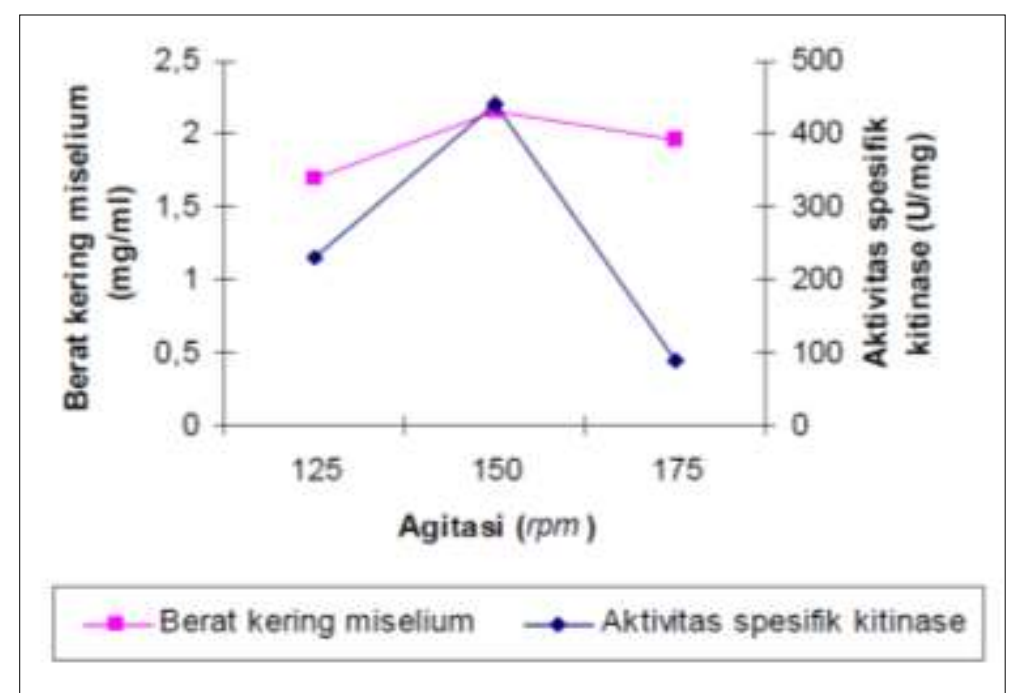

Gambar 4. Pengaruh agitasi terhadap aktivitas spesifik kitinase dan berat kering miselium isolat jamur TRK3

Agitasi mempunyai peranan yang penting dalam fermentasi substrat cair untuk percampuran nutrien dalam medium, transfer oksigen dan transfer panas. Agitasi juga akan menyebabkan kontak jamur dengan substrat menjadi lebih homogen, sehingga akan mempercepat perombakan substrat (Cui et al., 1997). Pada agitasi dengan kecepatan rendah menyebabkan percampuran nutrien dan transfer oksigen kurang merata karena miselium jamur akan tumbuh berbentuk berupa suatu lapisan, yang semakin lama menjadi tebal (Gandjar et al., 2006), sehingga kurang mendukung bagi pertumbuhan jamur yang akan mengakibatkan penurunan aktivitas kitinase.

Peningkatan kecepatan agitasi memang akan meningkatkan percampuran nutrien dan transfer oksigen, akan tetapi dapat menyebabkan perubahan morfologi seperti fragmentasi pada miselium, vakuolasi, autolisis dan pecahnya sel. Akibatnya pertumbuhan jamur tidak sempurna sehingga produksi kitinase juga menurun (Cui et al., 1997). Pada optimalisasi agitasi terhadap aktivitas kitinase yang dilakukan Liu et al., (2003), menunjukkan bahwa agitasi dengan kecepatan 225 dan 300 rpm menghasilkan aktivitas kitinase yang rendah. Pada penelitian ini dipilih agitasi dengan kecepatan 150 rpm yang menghasilkan aktivitas spesifik kitinase tertinggi.

\section{Waktu inkubasi}

Optimalisasi waktu inkubasi dilakukan selama 10 hari. Hasil optimalisasi menunjukkan bahwa aktivitas enzim spesifik kitinase dan berat kering miselium dipengaruhi oleh waktu inkubasi. Aktivitas spesifik kitinase dan berat kering miselium dari hari ke 0 akan meningkat sampai hari keempat, kemudian akan mengalami penurunan mulai hari kelima sampai hari kesepuluh. Pada hari ke 0 jamur belum menghasilkan kitinase karena jamur belum menunjukkan adanya pertumbuhan.

Kitinase mulai dihasilkan sesudah inkubasi 1 hari dengan aktivitas spesifik kitinase 160,2426 U/mg. Pada hari ke 4, aktivitas spesifik kitinase dan berat kering miselium jamur mencapai hasil yang tertinggi berturut-turut yaitu 587,7950 U/mg dan $2,7450 \mathrm{mg} / \mathrm{ml}$. 


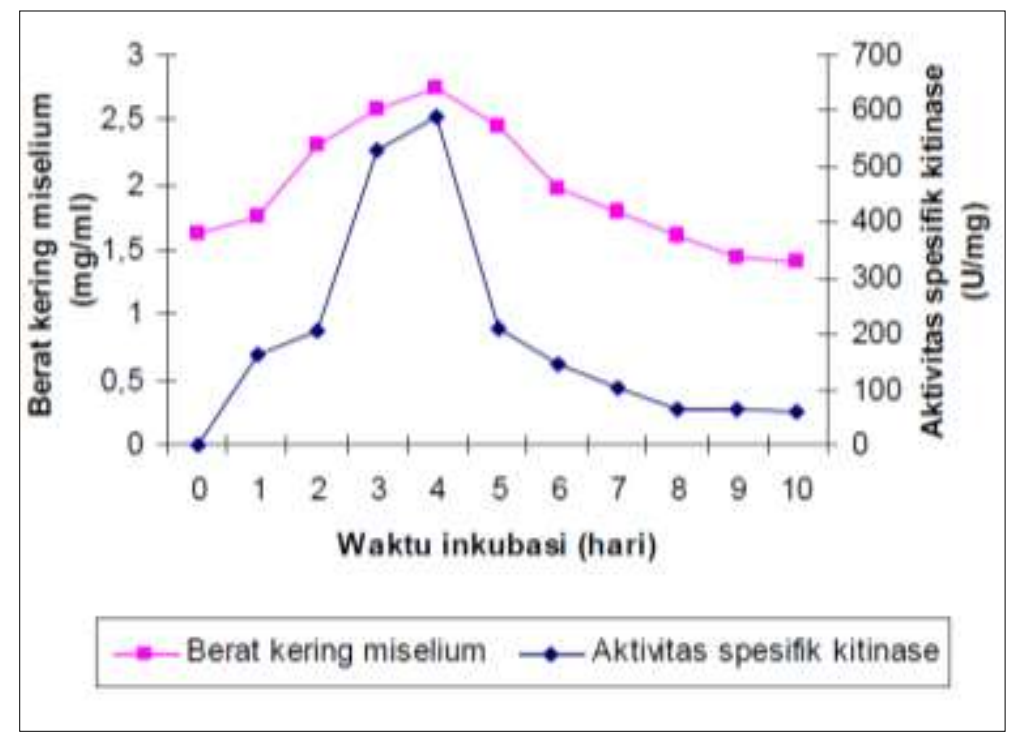

Gambar 5. Pengaruh waktu inkubasi terhadap aktivitas spesifik kitinase dan berat kering miselium isolat jamur TRK3

Waktu inkubasi isolat jamur TRK3 menghasilkan aktivitas kitinase dan berat kering miselium tertinggi berhubungan dengan pertumbuhan jamur yang berada pada fase logaritma. Pada fase ini sel-sel akan tumbuh dan membelah secara eksponensial sampai mencapai jumlah maksimum sesuai dengan kondisi lingkungannya. Semakin banyak jumlah jamur yang tumbuh maka kemampuan merombak kitin menjadi senyawa yang lebih sederhana menjadi meningkat. Hal ini dapat dilihat dari aktivitas spesifik kitinase yang tinggi.

Pada hari ke 5 sampai 10, produksi kitinase mengalami penurunan yang ditandai dengan menurunnya aktivitas spesifik kitinase. Hal ini disebabkan karena jumlah sel yang hidup mulai berkurang, metabolisme dan pertumbuhan sel mulai mengalami penurunan dikarenakan makin berkurangnya substrat. Selain itu dimungkinkan oleh adanya produk akhir yang berakibat pada terhambatnya aktivitas kitinase dalam memecah substrat.

\section{SIMPULAN DAN SARAN}

Pada penelitian ini aktivitas produksi kitinase jamur TRK3 yang optimum diperoleh pada konsentrasi kitin 0,2\% (b/v), $\mathrm{pH}$ optimal 5,5 , temperatur $30^{\circ} \mathrm{C}$, agitasi dengan kecepatan $150 \mathrm{rpm}$, dan waktu inkubasi optimal adalah pada hari keempat. Berdasarkan hasil optimalisasi produksi kitinase diketahui bahwa kemampuan jamur dalam memproduksi enzim selain ditentukan oleh spesies jamur, juga sangat dipengaruhi oleh kondisi lingkungan tempat tumbuh. Pada kondisi optimal diduga hampir semua substrat bereaksi dengan enzim sehingga menghasilkan produk yang maksimal.

\section{RUJUKAN}

Alexander, M. 1990. Introduction to Soil Microbiology. John Wiley and Sons Inc, New York.

Bielka, H., H.B.F. Dixon, P. Karlson, C. Liebeeg, N. Sharon, F.J. Van Lenten, S.F. Velix, J.F.G. Vliegenhart and E.C. Webb. 1984. Enzymes Nomenclature. Academic Press Inc, New York.

Cui, Y Q., Van der Lans, R.G.J.M and Luyben, K.C.A.M. 1997. Effect of Agitation Intensities on Fungal Morphology of Submerged 
Fermentation. Biotechno. Bioeng. 55 : $715-726$.

Deacon, J.W. 1984. Introduction to Modern Mycology. Blackwell Scientific Publications, London.

Elad, Y., I. Chet, P. Boyle and Y. Henis. 1983. Parasitism of Trichoderma spp. on Rhizoctonia solani and Sclerotium rolfsii. Phytopathology. 73: 85 - 88.

Gandjar, I., W. Sjamsuridzal and A. Oetari. 2006. Mikologi Dasar dan Terapan. Yayasan Obor Indonesia, Jakarta.

Haran, S., H. Schickler, A. Oppenheim and I. Chet. 1995. New Components of Chitinolytic System of Trichoderma harzianum. Mycol. Res. 94 : 441 446.

Harman, G.E., C.K. Hayes, M. Lorito, R.M. Broadway, A. Di Pietro, C. Peterbauer and A. Tronsmo. 1993. Chitinolytic Enzymes of Trichoderma harzianum : Purification of Chitobiosidase and Endochitinase. Phytopathology. 83 (3) : 313 - 318.

Li, D.C., S.H. Zhang, K.Q. Liu and J. Lu. 2004. Purification and Partial Characterization of A Chitinase from the Mycoparasitic Fungus Trichothecium roseum. J. Gen. Appl. Microbiol. $50: 35-39$.

Liu, B.L., P.M. kKao, Y.M. Tzeng and K.C. Feng. 2003 Production of Chitinase from Verticillium lecanii F091 Using Submerged Fermentation. Enzyme Microb. Technol. 33 : 410 - 415.

McQuilken, M.P and J. Gemmell. 2004. Enzyme Production by the Mycoparasite Verticillium biguttatum against Rhizoctonia solani. Mycopathologia. 157 : 201 - 204.

Murray, R.K., D.K. Granner, P.A. Mayes and V.W. Rodwell. 1997. Biokimia Harper. Penerbit Buku Kedokteran EGC, Jakarta.

Muzzarelli, R.A.A. 1985. Chitin. In G. O. Aspinal (Ed). The Polysaccharides.
Volume 3. Academic Press Inc, New York.

Sahai, A.S and M.S. Manocha. 1993. Chitinases of Fungi and Plants : Their Involvement in Morphogenesis and Host Parasite Interaction. FEMS Microbiol. Rev. $11: 317$ - 338.

Sandhya,C., L.K. Adapa, K.M. Nampoothiri, P. Binod, G. Szakacs and A. Pandey. 2004. Extracellular Chitinase Production by Trichoderma harzianum in Submerged Fermentation. J. Basic Microbiol. 44 (1) : 49 -58.

Simarmata, R., Lekatompessy, S. and Sukiman, H. 2007. Isolasi Mikroba Endofitik dari Tanaman Obat Sambung Nyawa (Gynura procumbens) dan Analisis Potensinya Sebagai Antimikrobia. Jurnal Penelitian Berkala Hayati : 13 (85-90).

Singh, P. P., YC. Shin, C.S. Park and Y.R. Chung. 1999. Biological Control of Fusarium Wilt of Cucumber by Chitinolytic Bacteria. Phytopathology. 89 (1) : 92 - 99.

Tweddell, R.J., S.H. Jabaji-Share and P.M. Charest. 1994. Production of Chitinases and â-1-3 Glukanases by Stachybotyrs elegans a Mycoparasite of Rhizoctonia solani. Appl. Environ. Microbiol. 489 - 495. Vessey, J.C and G.F. Pegg. 1973. Autolysis and Chitinase Production in Cultures of Verticillium albo-atrum. Trans. Br. Mycol. Soc. 60 : 133 - 134.

Wahyudi, P., U. Suwahyono, Harsoyo, A. Mumpuni dan D. Wahyuningsih. 2005. Pengaruh Pemaparan Sinar Gamma Isotop Cobalt-60 Dosis 0,25-1kGy terhadap Daya Antagonistik Trichoderma harzianum pada Fusarium oxysporum. Berk. Penel. Hayati. $10: 143$ - 151. 